УДК 346.543:338.439.64(4)

\author{
О. Білий,
}

аспірант кафедри господарського права і процесу

Національного університету «Одеська юридична академія»

\title{
ЗАБЕЗПЕЧЕННЯ БЕЗПЕКИ ПРОДУКЦІї В МІЖНАРОДНОМУ (ЕВРОПЕЙСЬКОМУ) ЗАКОНОДАВСТВІ
}

Насамперед наголосимо на тому, що питання безпечності харчових продуктів, харчування і продовольчої безпеки нерозривно пов'язані, адже небезпечні продукти харчування взаємопов'язані 3 різноманітними хворобами й недостатністю харчування. У зв'язку з цим постійно виникають нові загрози безпеки харчових продуктів. Зміни в технології виробництва харчової продукції, в розподілі та споживанні; навколишньому середовищі; патогени; бактеріальна резистентність - усі ці фактори створюють проблеми для національних систем безпеки харчових продуктів. Крім того, активізація пересування населення й торгівлі підсилює ймовірність міжнародного поширення небезпечних продуктів. Забезпечення населення продовольством у необхідній кількості, безпечним для життя і здоров'я, було й залишається однією з основних функцій держави. Урешті, безпека харчових продуктів - багатогранна проблема, яка зачіпає громадське здоров'я, економічні, політичні, соціальні, наукові й технічні аспекти. Тут особливо відмітимо той факт, що в сучасних умовах продукти виробляються 3 компонентів, які поставляються 3 різних регіонів та експортуються через глобальні виробничі мережі для продажу або подальшої переробки. Як наслідок, ризики, пов'язані із зараженням і забрудненням продуктів харчування, також набувають глобального характеру. Тож безпека харчових продуктів, порушена в одній країні, може становити значний ризик і для інших країн. Усе це, безумовно, становить інтерес до вибору означеної теми дослідження.

Дослідженню продовольчої безпеки присвячені праці В. Геєця, О. Гойчук, С. Кваші, А. Лисецького, А. Садєкова, О. Скидана та ін., проте питання безпечності продуктів харчування залишають місце для подальших наукових пошуків. Натоміть проблемам безпеки і якості харчової продукції присвячені наукові праці відомих вітчизняних і зарубіжних учених, а саме: В. Портера, П. Крюгмана, Р. Вернона, В. Гейця, О. Григоренка, Л. Дейнеко, О. Ільїної, Д. Крисанова, Т. Михальськи. Проте сучасний стан європейсько-міжнародного законодавства щодо безпеки продукції є динамічним і потребує детального відстеження.

Метою статті $€$ аналіз міжнародного та європейського законодавства у сфері безпеки продукції й виявлення правових засобів забезпечення продовольчої безпеки.

Провідна роль у нормативно-правовому забезпеченні і створенні надійної й ефективної системи державного регулювання у сфері безпечності та якості харчових продуктів належить $\in C$, де безпечність харчових продуктів визнається одним із пріоритетів політики. Наголосимо на тому, що безпека харчових продуктів - це спільна відповідальність. Вона повинна бути забезпечена на всьому протязі ланцюга виробництва харчових продуктів, починаючи від фермерів і виробників і закінчуючи продавцями і споживачами. На нашу думку, цей підхід має бути притаманний усім країнам. 




Сьогодні система вимог щодо безпеки продукції та процедур оцінювання відповідності в ЄС уважається найбільш ефективним та успішним прикладом усунення технічних бар'єрів у торгівлі. У країнах EC питання безпеки харчової продукції вирішуються в рамках самостійної галузі права - продовольчого права, яке регулює правовідносини на всіх стадіях виробництва, переробки і збуту харчових продуктів. Показово, що політика захисту прав споживачів є безпекоорієнтовною, а максимальний ефект захищеності продукції можливий за умови використання комплексу запобіжних заходів, спрямованих на досягнення високого рівня безпечності й якості, на що заздалегідь, безумовно, сподіваються та що очікують отримати споживачі.

Європейська технічна модель базується на принципах «нового» та «глобального» підходів, уперше сформульованих у 1985 та 1989 рр., які спрямовані на усунення технічних бар'єрів під час вільного переміщення товарів і послуг усередині $Є C$ шляхом єдиних вимог з безпеки до продукції та процедур оцінювання відповідності. Останні являють собою єдину загальноєвропейську правову базу, що визначає вимоги до продукції.

Відзначимо, що так званий «новий підхід» у технічному регулюванні запроваджено в ЄС у 1985 р., його основою стало правило, за яким тільки найголовніші вимоги містилися в директивах, деталізовану інформацію щодо вимог покладено на CEN та інші спеціалізовані органи. Базові директиви 3 узагальнених правил безпеки товарів - 85/374 та 2001/95.

Європейський Союз вибрав подвійний підхід до гармонізації законів про продукти харчування: а) «горизонтальне» законодавство - стосується загальних аспектів (добавки, маркування, гігієна); б) «вертикальне» законодавство по конкретних продуктах (м'ясо, риба, цукор, борошно тощо).

Відносини, що пов'язані з безпекою харчових продуктів, у законодавстві EC урегульовані низкою норматив- них актів. Їх можна охарактеризувати як детальний опис вимог до процесу виготовлення продуктів, безпеки складників продукту, певних продуктів. Серед особливих норм варто назвати застосування встановлених стандартів до сільськогосподарських продуктів і кормів для тварин. Регламенти й директиви із цих питань охоплюють усю сферу, галузь, наприклад, пов'язану 3 харчовими барвниками, що регулює загальні питання, а щодо формулювання стандартів у цій сфері з технічного боку, то це покладено на спеціалізовані органи зі стандартизаціï (наприклад, CEN). Різні Директиви вимагають, щоб усі товари, які продаються споживачам, були настільки безпечними, наскільки це можливо, i містять критерії, яким продукція повинна відповідати для забезпечення цього. Виробники й імпортери несуть відповідальність за безпеку товарів, які вони продають. У кожній країні повинні існувати органи, відповідальні за перевірку відповідності вимогам i виведення небезпечної продукції з ринку, якщо це потрібно.

Основоположними цілями законодавства є захист інтересів споживача: недопущення шахрайства й обману, підробки, надання неправдивої інформації; забезпечення потреб споживача, наявність повної інформації про продукт, щоб споживач міг правильно підібрати їжу відповідно до особливостей організму [1].

Метою законодавства ЄС щодо безпечності харчових продуктів є забезпечення високого рівня захисту життя, здоров'я та інтересів споживачів, чесних практик торгівлі харчовими продуктами, захист здоров'я тварин та умови їх утримання, здоров'я рослин і довкілля. Комплексний та інтегрований підхід до питання безпечності харчових продуктів також відображено в зобов'язаннях країн-членів не тільки стосовно своїх громадян, а й усіх громадян ЄC і третіх країн у тому, що стосується харчових продуктів, вироблених на їхній території. Крім того, європей- 
ське ставлення до питання безпечності харчових продуктів і захисту інтересів споживачів - це питання не тільки державних інституцій (як підкреслено Регламентом № 178/2002 [2]), а й громадськості, неурядових організацій, професійних асоціацій, міжнародних торгових партнерів і торгових організацій. Основоположним документом $Є С$ у сфері безпечності та якості харчових продуктів (ідеться про Регламент № 178/2002 Європейського парламенту і Ради ЄC від 28.01.2002 [2]) визначено загальні принципи продовольчого права ЄС. Щодо продовольчих продуктів установлено такі вимоги: тільки безпечне продовольство має бути розміщено на ринку; держави-члени ЄC повинні здійснювати аналіз ризиків продукції, що включає оцінювання (наукове консультування й аналіз інформаціі), управління (регулювання та контроль), взаємодію (швидкий обмін інформацією); орган із безпеки продо-вольства (Європейська агенція 3 питань безпеки продуктів харчування) має здійснювати наукове консультування та підтримку, обмін інформацією. Усі вимоги до харчових продуктів поширюються на всі стадії виробництва, обробки, збуту харчових продуктів і повинні дотримуватися як стосовно товарів, вироблених у $\in C$, так й імпортованих із третіх країн. Ці принципи закладено в основу національного законодавства держав-членів $€ C$, і вони є орієнтиром для держав, що перебувають на шляху євроінтеграціï [3, с. 77].

Важливими серед норм щодо харчових продуктів $€$ норми про інформацію, пов'язану зі здоров'ям (Регламент 1924/2006). Щодо останньої передбачено спеціальний Реєстр, причому інформація про харчі має містити тільки ті формулювання, що їх використано в законодавстві.

Для належного забезпечення безпеки продукції передбачено також норми щодо матеріалів і предметів, які можуть вступати у взаємодію 3 продовольством, оскільки така взаємодія може прямо або опосередковано спричинити шкідливі трансформації в харчах. Базовий принцип у регулюванні цього питання: такі матеріали та предмети повинні бути вироблені відповідно до «чесної виробничої практики» 3 урахуванням нормальних або передбачуваних умов користування, за яких ї взаємодія з продовольством не буде шкодити здоров'ю людини чи викликати небажані зміни в продовольчому продукті або погіршувати його характеристики. Існують також окремі правила щодо таких видів матеріалів, як кераміка, целюлоза, пластик, що включають списки дозволених субстанцій, стандарти достатньої якості, ліміти взаємодії матеріалів і продуктів.

Загальна безпека продукції встановлюється Директивою 2001 / 95 / ЄС [4], якою також визначаються обов'язки держав-членів щодо нагляду за ринком для забезпечення безпеки споживчої продукції, а також настановами ЄC щодо виконання директив «нового підходу». Мета $\dddot{1 і}$ - виробники зобов'язані виводити на ринок лише безпечну продукцію. Загальний порядок та умови розміщення продукції на внутрішньому ринку ЄС, проведення робіт 3 оцінювання відповідності й акредитації, а також механізм ринкового нагляду окреслені в Регламентах Європейського Парламенту й Ради ЄС, зокрема № 764/2008, № 765/2008, і Рішенні від 9 липня 2008 р. № $768 / 2008$. Вагоме значення під час здійснення наглядової діяльності на ринку має й Директива «Про наближення законів, постанов та адміністративних положень держав-членів щодо відповідальності за неякісну продукцію» 85/374/ ЄЕС від 25 липня 1985 р. [5].

Директива 2001/95/ЄС установлює загальні вимоги до безпеки, відповідно до яких виробники зобов'язані розміщувати на ринку тільки безпечну продукцію. Деякі країни забезпечили безпосереднє законодавче закріплення цієї Директиви (зокрема Греція, Ірландія, Кіпр, Словенія тощо), але більшість інших країн пішли шляхом інтеграції 


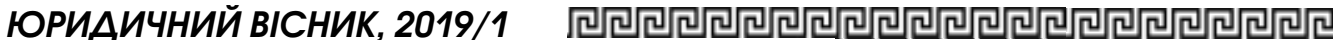

положень Директиви до наявного законодавства щодо безпечності продукції та захисту прав споживачів. В обох випадках національне законодавство у сфері технічного регулювання містить спеціальні розділи з ринкового нагляду за продукцією, розміщеною на ринку, а також установлює повноваження інституцій ринкового нагляду та права іх посадових осіб.

Директива містить певні критерії:

- відповідність чинним національним законам;

- відповідність європейським стандартам охорони здоров'я та якості продукції, які ухвалені як національні стандарти;

- відповідність іншим чинним національним стандартам, керівним документам ЄC, кодексам ведення бізнесу;

- використання передових технологій;

- відповідність обгрунтованим очікуванням споживачів.

Директива 2001/95/ЄС установлює вимоги до всіх учасників ланцюга постачання, а саме:

- виробники можуть розміщувати на ринку тільки безпечну продукцію;

- усі учасники економічного процесу несуть відповідальність за безпечність продукції, яку вони розміщують на ринку;

- учасники економічного процесу повинні інформувати органи влади, якщо вони розмістили небезпечну продукцію на ринку, і співробітничати 3 органами влади 3 метою іiі відкликання з ринку [4].

Якщо продукція створює проблеми, пов'язані з безпекою, виробники зобов'язані надавати інформацію споживачам, а також відкликати таку продукцію з ринку, якщо це необхідно. Дистриб'ютори повинні також вести належний облік для забезпечення можливості відслідковування продукції (а також шляхів походження продукціï або дефектних компонентів), моніторингу продукції на предмет ризиків, а також поширення інформації стосовно можливих проблем.
3 боку уряду повинен бути призначений орган, який несе відповідальність за моніторинг і забезпечення виконання вимог безпеки і який також:

- здійснює ринковий нагляд, беручи й перевіряючи зразки продукції;

- вимагає розміщення попереджувальної інформації у випадках, коли вживання продукції пов'язане $з$ ризиком;

- уживає заходів у разі виникнення проблем, вимагаючи тимчасового призупинення продажів продукції або повного їі виведення з ринку;

- створює можливості й механізми подання скарг споживачами щодо потенційно шкідливої продукції або щодо подання інформації про фактичні інциденти, пов'язані 3 невідповідним рівнем безпеки.

EC розвиває також інші програми, спрямовані на підвищення безпеки.

3 метою забезпечення безпеки споживачів і їх захисту від ризиків, які можуть бути призведені продукцією, Директива 2001/95/ЄС передбачає необхідність розроблення правил, що регулюють функціонування спеціальної системи «РАПЕКС» (від англ. RAPEX Rapid Exchange of Information System, система швидкого обміну), що призначена для швидкого обміну між державами-членами та Європейською Комісією інформацією про серйозні ризики для споживачів, з метою розроблення й виконання спільних проектів нагляду та випробувань.

Разом із тим аналіз законодавства ЄС щодо безпеки продукції дає можливість зробити висновок, що розвиток законодавства $\in C$ у цій галузі зумовлений багатьма чинниками, серед яких особливе місце належить науково-технічному прогресу та змінам у загальному підході ЄС до здійснення правового регулювання. При цьому зміна загального підходу мінімальної гармонізації на максимальну гармонізацію впливає на форму вираження норм права, а такий підхід до зближення законодавств, як повна гармонізація, вимагає невідкладного запровадження, 
що пояснюється необхідністю досягти однаковості правового регулювання відносно продукції, яка надходить на внутрішній ринок, що, на думку законодавця, сприятиме підвищенню загального рівня безпеки продукції та захисту здоров'я споживачів.

Основні напрями Європейської концепції забезпечення безпеки харчових продуктів такі: виробник несе повну фінансову та юридичну відповідальність за безпеку продукціі, яку він виготовляє, й обов'язкове введення системи НАССР.

У грудні 2018 р. Генеральна Асамблея ООН своєю Резолюцією (A/RES/73/250) проголосила 7 червня Всесвітнім днем безпеки харчових продуктів (World Food Safety Day). Засновуючи цей Усесвітній день, ООН ставила своїм завданням залучення уваги держав до проблем здорового харчування населення, а також якості вироблених харчових продуктів. Заклик звернений як до владних структур, так і до виробників харчової продукції та працівників сфери їх збуту (фермерів, працівників сільського господарства, харчової промисловості й працівників торгівлі).

У міжнародній практиці основою для забезпечення безпеки продовольства став Кодекс аліментаріус (Codex Alimentarius). Кодекс аліментаріус - це збірник міжнародно схвалених і поданих в однаковому вигляді стандартів на харчові продукти, розроблених під керівництвом $\mathrm{FAO} / \mathrm{WHO}$, спрямованих на захист здоров'я споживачів і гарантування чесної практики в торгівлі ними. Зазначений збірник підготовлений і виданий Комісією Кодексу аліментаріус. Комісія Кодексу аліментаріус (англ. Codex Alimentarius Commission) створена в 1963 р. Продовольчою та сільськогосподарською організацією ООН (FAO) і Всесвітньою організацією охорони здоров'я (WHO) як їхній допоміжний орган для впровадження спільної $\mathrm{FAO} / \mathrm{WHO}$ програми стандартів на продукти харчування [6, с. 173].
Найбільше значення для міжнародної торгівлі продовольством мають дві угоди Світової організації торгівлі (СОT): Угода про застосування санітарних і фітосанітарних заходів, яка стосується заходів, що застосовуються для охорони здоров'я людей, тварин і рослин, та Угода про технічні бар'єри в торгівлі, яка стосується технічних нормативів і методик оцінювання їх дотримання й поширюється на всі товари, а не тільки на харчові продукти.

За безпеку харчових продуктів Угода про застосування санітарних і фітосанітарних заходів дає посилання на стандарти, розроблені Комісією «Codex Alimentarius» в наступних галузях: 1. Харчові добавки. 2. Залишки ветеринарних лікарських препаратів і пестицидів. 3. Забруднювальні домішки. 4. Методи аналізу й відбору проб. 5. Гігієнічні норми та правила

Угода про ТБТ покликана гарантувати, що технічні норми і стандарти, в тому числі й правила пакування та маркування, а також процедури аналізу відповідності технічним нормам і стандартам, не створюють непотрібних перешкод торгівлі.

Стандарти, методичні вказівки й інші рекомендаціï «Codex Alimentarius», що стосуються харчових продуктів, грунтуються на принципі серйозного наукового аналізу та наукових доказів, які передбачають ретельну перевірку всіх істотних даних, щоб ці стандарти могли гарантувати якість і безпеку харчових продуктів.

У публікації ВООЗ «П'ять найважливіших принципів безпечного харчування» подається практичне керівництво для продавців і споживачів у галузі обробки та підготовки продуктів харчування: Принцип 1. Зберігайте продукти в чистоті. Принцип 2. Відокремлюйте сирі продукти від продуктів, які зазнали теплової обробки. Принцип 3. Піддавайте продукти ретельній тепловій обробці. Принцип 4. Теплова обробка проводиться за необхідної температури. Принцип 5. Користуйтеся 


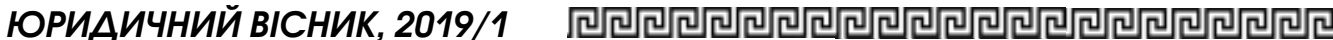

безпечною водою й безпечними сирими продуктами.

Міжнародні стандарти з безпеки харчової продукції вимагають упровадження системного підходу, який передбачає, що виробники харчової продукції будуть на добровільній основі аналізувати ризики й упроваджувати відповідні програми щодо запобігання виникненню небезпек у критичних контрольних точках, які також називають планом НАССР (Hazard Analysis and Critical Control Points - Аналіз ризиків і критичні контрольні точки).

32005 р. діє новий міжнародний стандарт ISO 22000 «Системи менеджменту безпеки харчової продукції. Вимоги до будь-яких організацій продуктового ланцюга», який створений для гармонізації вимог міжнародного стандарту CODEX ALIMENTARIUS i національних вимог, наприклад, у галузі санітарії та гігієни. Цей стандарт разом 3 іншими міжнародним стандартом ICO 22004 «Системи менеджменту безпеки харчових продуктів. Настанови щодо застосування ICO 22000: 2005» містить вимоги й рекомендації щодо впровадження системи управління безпечністю харчової продукції.

До цієї серії належить і стандарт ICO 22005, що містить загальні принципи та керівні вказівки 3 проектування й розроблення систем, які забезпечують простежуваність у кормовому і продуктовому ланцюгах.

Додатковий міжнародний стандарт ICO 22003 встановлює вимоги до органів, що здійснюють аудит і сертифікацію систем управління безпечністю харчової продукції. Отже, організації, що впровадили систему управління безпечністю харчової продукції, можуть пройти міжнародну сертифікацію на відповідність вимогам ISO 22000 в уповноважених органах із сертифікаціі.

Отже, проблема безпечності продукції розглядається на міжнародному та європейському рівнях досить при- скіпливо, про що свідчить наявна нормативно-правова база. Серед правових засобів забезпечення безпеки продукції можемо виокремити такі компоненти, як директиви, Кодекс і міжнародні стандарти.

Ключові слова: безпека, продукція, безпека продукції, забезпечення безпеки продукції, законодавство.

У статті розглядаються положення міжнародно-європейського законодавства щодо безпеки продукиіі. Виокремлено фундаментальні директиви Європейського Союзу з означеного питання та висвітлено іх головні положення. Приділено увагу базовому Кодексу з безпеки продукиії й міжнародним стандарmaм.

В статье рассматриваются положения международно-европейского законодательства касательно безопасности продукции. Выделены фундаментальные директивы Европейского Союза по указанному вопросу и освещцены их основные положения. Уделено внимание базовому Кодексу по безопасности продукиии и международным стандартам.

The article deals with the provisions of international-European legislation on product safety. The basic Directives of the European Union are outlined on this issue and highlighted their main provisions. The basic code of safety products and international standards are paid attention.

\section{Література}

1. Толок Г.А., Толок Є.В. Екологічні засади забезпечення якості та безпеки харчових продуктів. Ефективна економіка. 2018. URL: http: / / wrereconomy.nayka.com.ua/ $p d f / 6 \_2018 / 50 . p d f$.

2. Про встановлення загальних приниипів $і$ вимог законодавства про харчові продукти, створення Європейського органу з безпеки харчових продуктів і встановлення процедур у питаннях, пов'язаних із безпекою харчових продуктів : Регла- 


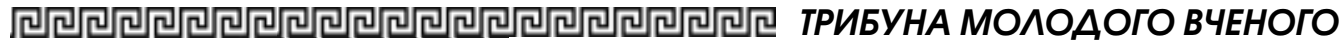

мент (ЕС) Європейського Парламенту $i$ Paдu від 28.01.2002 № 178/2002. URL: http: / / old.vet.gov.ua/int-coop / EU_ requirement.

3. Брулевич В.В. Безпечність харчових продуктів за законодавством України та Європейського Союзу. Судова апеляиія. 2016. № 2. C. 75-83.

4. Directive 2001/95/EC of the European Parliament and of the Council of 3 December 2001 on general product safety. Official Journal L 11, 15.01.2002 P. 4-17.
5. Council Directive $85 / 374 /$ EEC of 25 July 1985 on the approximation of the laws, regulations and administrative provisions of the Member States concerning liability for defective products. Official Journal L 210, 07.08.1985 P. 0029-0033.

6. Пчелянська Г.О. Безпека та якість продовольчих товарів: міжнародний аспект. Збірник наукових праць Вінницького національного аграрного університету. Серія "Економічні науки». Вінниця, 2012. T. 2. № 3 (69). С. 172-177. 